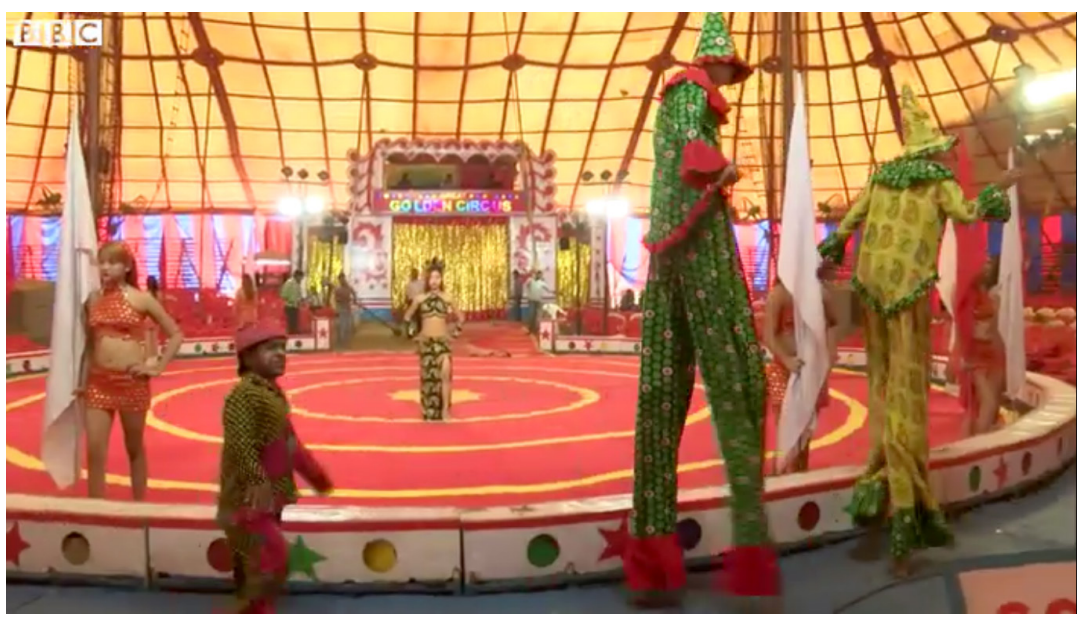

Image credit: BBC News India

\title{
Will the Circus come to town? : Indian Circus Arts swinging between a Kafka moment and a nouveau moment
}

Anmol Mongia teaches at the Department of Sociology, Salesisn College, Sonada.

Circuses in India and elsewhere are both an art form and a life tool. As most observers of the Indian Circus are sounding its death knell, this article explores if there is still hope of revival for the once esteemed performing art form.

Franz Kafka in his short story "The Hunger Artist" (1922) describes the transition of a performance that would hold its audiences spellbound at a time, into one that no longer amuses people. In those earlier times, the hunger artist would exhibit his fasting for forty days, stationed inside a cage lined with straw and wardens to ensure he doesn't eat secretly, and people would watch him with excitement day after day. "In better times, hunger performances could be displayed as a self-sufficient sensation in the world's largest venues" but Kafka writes that "during these last 


\section{4 / Anmol Mongia}

Salesian Journal of Humanities and Social Sciences, Vol. XI, No.2 (Dec 2020)

ISSN: 0976-1861 | DOI: 10.51818/SJHSS.11.2020.123-129 | Page: 123-129,

Section: Articles

decades, the interest in hunger artists has markedly diminished."1 With the decline in public interest in hunger art, Kafka's artist figure, "after some vain attempts to revive the dying genre," decided to join a large circus. ${ }^{2}$ At the circus his cage and his emaciated self became the site of a mere passing glance of the crowds with shorter attention spans, who had come to witness the spectacle of acrobatic performances and wild animals. Kafka's artist carried a heavy heart for "he was working honestly, but the world was cheating him of his reward...[and] [c]oncealed among his straw, he set records that went unnoticed." 3

The irony is that in this piece, we are talking of the circus that once enthralled and overshadowed other arenas of arts and entertainment itself becoming a dying art form. Around the world, the lights are going out in the circus rings. ${ }^{4}$ American Barnum and Bailey Ringling Bros staged their last show in 2017-after staging for 146 years-owing to the dropping sales and viewership. The Great Bombay Circus (GBC), one of the oldest troupes of India is going to mark its centenary year in 2020, admits to having a tough time running its shop. ${ }^{5}$ GBC used to rent the ground from Southern Railways and every time they arrive in Chennai now, the ground shrinks in size, 'I' $m$ not sure if there will be any ground left in a few years to hold a circus' ${ }^{6}$ laments the managing partner and promoter of the company, KM Sanjeev. There are no takers of their art. This is the case with most circuses in India. Juggling, trapeze act, tightrope walking, clown show, acrobatics, daredevilry of sword swallowing, motorcycle stunts no longer hold the interest of a public that has many digitised avenues of entertainment accessible to them.

\footnotetext{
${ }^{1}$ Peter Sloterdijk, You Must Change Your Life: On Anthropotechnics, trans. by Wieland Hoban, (Cambridge: Polity Press, 2013), 69.

${ }^{2}$ Ibid.

${ }^{3}$ Ibid, 70 .

${ }^{4}$ https://thewire.in/culture/great-bombay-circus.

${ }^{5}$ https:/ / www.thehindu.com/ society / circus-is-about-to-go-extinct-in-india/ article30514120.ece.

${ }^{6}$ Ibid.
} 


\section{Decline through bans: First animals and then children}

For many of us in urban India, the term Circus awakens childhood memories of being seated in a large tent and finding entertainment by gazing at a lion being controlled by a ringmaster for the first time, or an elephant's balancing act on a small table would bring the awe. In 1991, the environment ministry banned the training and performance of wild animals-lions, tigers, panthers, monkeys, bears and bulls - the major crowd drawing elements of Indian circuses. The ban served a major blow to the circus businesses in the country. Owing to the ban and competition from the modern entertainment industry, it has been documented that the number of circus companies has dropped from 300 in 1990 to about 30 at present, and falling still. Most troupes in India, these days, showcase performances by trained dogs, camels, horses, macaws and cockatoos but the ministry, in 2018 passed the proposal to ban all animals from circus performances as the animal rights campaign against circuses mounted.

In 2011, the Indian Supreme Court ordered a ban on employment of children below 14 years of age to perform or be employed with circus companies. The Supreme Court bench, in response to the petition by Nobel peace prize winner Kailash Satyarthi led NGO Bachpan Bachao Andolan, directed that raids be conducted in circus companies and children be liberated. ${ }^{7}$ The petition argued that children working in circuses underwent exploitative labour, sexual abuse, bondage and slavery. Major circuses faced a crunch in performers following the ban. The ban has made little sense for an art form which depends on artists who are moulded into their talents from a very young age.

First animals and then children, the Indian circus fraternity faced its fateful moment at the time of the ruling. Governments, over the decades have shown reduced recognition and withdrawn support

7 P.R. Nisha, "Children and the Indian Circus," Economic and Political Weekly 46, 33 (2011): 23-25. Accessed September 26, 2020. http://www.jstor.org/ stable/23017839. 


\section{6 / Anmol Mongia}

Salesian Journal of Humanities and Social Sciences, Vol. XI, No.2 (Dec 2020)

ISSN: 0976-1861 | DOI: 10.51818/SJHSS.11.2020.123-129 | Page: 123-129,

Section: Articles

from the circus industry. The Circus Owner's Federation and the Circus Employees' Union filed a petition against the animal ban ruling and argued that the order threatened the lives of around 40,000 animal trainers/caretakers/handlers/performers. ${ }^{8}$ It also argued that a century old historical tradition of animal training and performance was being threatened. However, none of the animal trainers and other related professionals were compensated. With the ban on employment of children, complex debates surfaced regarding the status of working children. ${ }^{9}$ While circuses around the world are facing bans on animal performances, most continue to employ children who undertake important professional roles in big shows. Moreover, circus is an art form that takes years of dedicated practicing, through daily rigorous routines. The answer to the question - should children be allowed to be professionals of an art form that requires living a challenging regimen and giving death defying performances, may seem simple to contemporary readership most of whom agree that childhoods must be protected. However, it is a complex answer if one perceives the matters from behind the curtain of a circus.

\section{The journey of the Big Top from the Traditional to the New}

Traditionally, circus has been an itinerant art form, involving troupes making tours around the world to set up their show. Circuses in most parts of the world continue to be composed of families that travel together with crew and menagerie, and perform together. Children are brought up in nomadic lifestyles and practice routines consistent with those of their parents. But in most of Europe, nouveau circus or 'new circus' has largely replaced the traditional itinerant circus. France, for instance still boasts of an ever growing and evolving circus culture and is spearheading the face of the new circus with the advent of circus schools. Circus schools have opened up the circus world to outsiders, which in its traditional form did not offer opportunities to those who didn't belong to circus families.

${ }^{8}$ Ibid.

${ }^{9}$ Ibid. 
New Circus, as it has come to be called, takes traditional circus skills and redefines them. The changes in elements such as venue, costume and music accompanied by artistic use of more everyday objects as props and innovative performances at newly created festivals ${ }^{10}$ has given the art form in the region a renaissance. And most importantly, New Circus doesn't have to be performed under a big tent, and there are never animals involved. ${ }^{11}$

In India, however, the Circus has had a different trajectory. Originally it followed the model of the British and European circuses of the late 19th century but from the 1920s to 60s, most Indian circus performers came from the state of Kerala trained in the indigenous martial art form Kalaripayattu (Kalari). The Circus offered an alluring prospect to people from socially and economically backward communities of the region (Skidmore 2014, 221). ${ }^{12}$ True to its nature elsewhere, circus in India too became a space offering a community to people. The same discriminatory practices facing lower castes or minority religious communities in Indian society were not found at the circus. (An exception exists in the form of the nomadic group of acrobats, entertainers and jugglers called Bazigarsand Natshailing mostly from the North Indian states of Punjab and Haryana) As it began to draw participants from across India, and later from Nepal, the Circus grew as a form of entertainment. Most who joined the circus were from lower social strata with poor economic conditions. Many children from such struggling families were joining the circus from Nepal, Assam, Meghalaya, Bengal. And this is still the case.

\section{Challenges facing Indian Circus}

Indian Circus is still an itinerant and nomadic affair. Here, the circus business is fraught with challenges of huge overhead costs

${ }^{10}$ https://theculturetrip.com/europe/france/paris/articles/a-brief-history-ofthe-circus-in-france/.

${ }^{11}$ https:// www.france24.com/en/20170221-circus-france-ever-growing-art-form.

${ }^{12}$ Jamie Skidmore, "Defying Death: Children in the Indian Circus", in Entertaining Children The Participation of Youth in the Entertainment Industry, edited by Gillian Arrighi and Victor Emeljanow, (New York: Palgrave Mcmillan,2014), 219-234. 


\section{8 / Anmol Mongia}

Salesian Journal of Humanities and Social Sciences, Vol. XI, No.2 (Dec 2020)

ISSN: 0976-1861 | DOI: 10.51818/SJHSS.11.2020.123-129 | Page: 123-129,

Section: Articles

of travelling with crew, animals and equipment. The artists live on alarmingly little rest and recovery time as they perform back to back shows. And although it is an art form that thrives on its quality to play with danger, it has been argued that Indian circuses make children perform the same dangerous stunts that adults perform like fire-breathing act that is performed by adults, teens and children in most Indian circuses. The Indian Circus landscape has also been accused of giving paltry wages, child beating and routine sexual harassment of girls and women. The list is long and many may find themselves stuck in the profession as they have no other skills to earn a living, while yet others, like Kafka's artist, want to perform for the love of performance but the world remains indifferent to their craft.

For many within and outside of the Circus community, the stage of the circus holds an extraordinary appeal that no other platform can substitute for. Some of these are veterans who have spent their entire lives in the industry and others who are growing up aspiring to be part of it. Scholars have argued that if the State wants circus acrobatics to survive in this part of the world, they should work towards revival by building a circus "safe" environment that nurtures artists. A structural change aside, adequate training academies and a system of formal education should be introduced for child circus artists who want to grow in the field.

If we go by the latest reports on Indian Circus arts, its future looks very bleak as it appears to reach the tail end of its career. However, its revival is possible if we believe the optimism brewing in the work of Aditya Shah and Sugandhan Ashokan who want to transform the Indian circus industry by bringing live circus shows to mobile phones through an OTT streaming platform. Seeing the miserable conditions of stranded circus crews during the Covid-19 lockdown, they ran a crowd funding campaign and raised Rs 1 crore to support various crews struggling to make ends meet in different parts of the country. Soon, they began to study international 
circuses and charted their pivots. ${ }^{13}$ They are finalizing the script of a documentary ${ }^{14}$ which will chart the journey of Indian circus, along with boosting the presence of circuses on social media. Who knows, with the digital revolution and immersive technologies, the nouveau moment of Indian Circus may be just around the corner. indian-circus-11596103480298.html.

${ }^{14}$ Ibid. 